\title{
Comparison of English Vocabulary Learning Strategies for Good and Weak Learners at King Mongkut's Institute of Technology Ladkrabang
}

\author{
Khanadee Rojananak and Jirapa Vitayapirak
}

\begin{abstract}
The purposes of this study were to find out the vocabulary learning strategies that the second year students of King's Mongkut's Institute of Technology Lakrabang commonly use and compare the vocabulary learning strategies between good and weak students. The sample was 356 second-year students in 9 faculties: Engineering, Architecture, Industrial Education, Science, Agribusiness Administration, Agricultural Industry, Information Technology, Nanomaterial Engineering, and Management Technology. The research instrument used in collecting the data were a five-point Likert scale questionnaire adopted from Schmitt's taxonomy for vocabulary learning strategies. The quantitative data were analyzed using the descriptive statistics of arithmetic mean and standard deviation, and independent sample t-test. The results of the study revealed that English vocabulary learning strategies that the second year students commonly use is using an English-Thai dictionary ( $\bar{x}=\mathbf{2 . 8 6}$ ), strategies that good students use is guessing the meaning from context $(\bar{x}=3.32)$ whereas strategies that weak students use is asking their classmates for the meaning $(\bar{x}=\mathbf{2 . 8 5})$. The result from Independent sample t-test showed statistical significant difference between good and weak students $(p=0.00 * *)$. This study confirmed earlier reported findings that good language learners are heavily dependent on bilingual dictionaries for their English vocabulary learning.
\end{abstract}

Index Terms - Vocabulary, learning strategies, good learners, weak learners, Thai.

\section{INTRODUCTION}

Vocabulary has always been a crucial part of language learning and teaching. However, vocabulary teaching has not been receptive to problems in the area, and most language teachers have not recognized the great communicative advantage in developing an extensive vocabulary [1]. Vocabulary often seems to be the least systematized and the least well-catered for of all the aspects of learning of foreign language such as listening, speaking, reading, writing, grammar or even pronunciation. Many researchers such as [1]-[8] have said that vocabulary studied have been neglected, and paid less attention and so little importance has been given to vocabulary in modern language teaching. There is a lack of attention to vocabulary [4]. Furthermore, some researcher gave a notable reason for the neglect of vocabulary that

Manuscript received September 29, 2014; revised January 20, 2015.

Khanadee Rojananak is with the Dept. Applied Linguistics (English for Science and Technology), King Mongkut's Institute of Technology Ladkrabang, Thailand (e-mail: nady-2513@hotmail.com).

Jirapa Vitayapirak is with the Division of Applied Arts (English), Faculty of Industrial Education, King Mongkut's Institute of Technology Ladkrabang, Thailand (e-mail: kvjirapa@kmitl.ac.th). learners themselves do not place considerable significance on vocabulary [3]. The neglect of vocabulary is mainly due to the fact that teachers have been told a great deal about new discoveries in English grammar, but they have heard much less about ways to help students learn new words.

Since vocabulary learning is part of language learning and teaching, it is also worth mentioning in the present study that strategies should be indispensable parts of vocabulary learning and teaching. It is necessary for language learners to be taught vocabulary learning strategies in order that they can learn how to discover the meaning of new words, how to store them in their memory, how to practice with them and how to expand their vocabulary. These strategies are essential tools for developing communicative competence [9]-[13].

In language learning, it is unavoidable for language learners and teachers to deal with vocabulary and vocabulary learning strategies. Through an extensive review of related literature and available research works on vocabulary learning strategies, the researcher has noted that past researchers have paid little attention to vocabulary learning when compared with other aspects of language, such as grammar, phonology or discourse analysis. In the context of English as a foreign language (EFL) in Thailand, it is found that very few empirical research works have been conducted to investigate vocabulary learning strategies used by students at the university level in Thailand.

This research is thus interesting in investigating the English vocabulary learning strategies commonly used by good and weak Thai students. The finding is an important reflection on how Thai English learners use English vocabulary learning strategies and also how good and weak proficient learners of English differ in their use of strategies and will also serve as resource in the development of English vocabulary learning and teaching in Thailand.

\section{OBJECTIVES OF THE STUDY}

The objectives of this research were:

1) To find out the vocabulary learning strategies that the second year students of King Mongkut's Institute of Technology Ladkrabang commonly use.

2) To compare the vocabulary learning strategies used by good and weak students.

\section{Population AND SAmPle}

The population was the second year students of King Mongkut's Institute of Technology Ladkrabang studying 
English in the second semester of academic year 2013. The sample of the study was 365 students who were selected by using the Hendel's random sample table at the $95 \%$ confidence level (shown in Table I). These students were divided into two groups, good and weak learners by using (1) the score of Foundation English course and (2) the score of vocabulary test.

TABLE I: THE POPULATION AND SAMPLE SIZE

\begin{tabular}{|l|c|c|}
\hline \multicolumn{1}{|c|}{ Study Program } & Population & Samples Size \\
\hline Engineering & 1538 & 103 \\
\hline Architecture & 542 & 36 \\
\hline Industrial Education & 550 & 37 \\
\hline $\begin{array}{l}\text { Agribusiness } \\
\text { Administration }\end{array}$ & 747 & 51 \\
\hline Science & 1253 & 85 \\
\hline Agricultural Industry & 226 & 15 \\
\hline Information Technology & 109 & 8 \\
\hline Nanomaterial Engineering & 46 & 3 \\
\hline Management Technology & 268 & 18 \\
\hline Grand Total & 5279 & 356 \\
\hline
\end{tabular}

\section{MATERIALS AND METHOD}

\section{A. Research Instruments}

Research instruments of this study were English vocabulary test, and frequency questionnaire.

1) English vocabulary test was developed by researcher basing on Norbert Schmitt vocabulary test. This test was used to measure the vocabulary proficiency of learners that correlate with their score of Foundation English course.

2) Questionnaire was used to measure the frequency of the vocabulary learning strategies. It consisted of two parts: the subject's personal information, and 40 questions relation to the strategies that the students might have used.

\section{B. Research Methodology}

This research is a descriptive research using English vocabulary test, and survey-questionnaires, to obtain the information on the English vocabulary learning strategies of second year students of King Mongkut's Institute of Technology Ladkrabang.

\section{Data Collection and Analysis}

The questionnaire and the English vocabulary test were given to all subjects. After analyzing the result, all subjects were divided into two groups, good and weak learners by using the scores of Foundation English course and scores of English vocabulary test. The data obtained from the English vocabulary test and the frequency questionnaire which were analyzed by using mean, standard deviation, percentage, Independent sample T-test, and correlation.

\section{REsUlts}

\section{A. Most and Less Used Vocabulary Learning Strategies of} All Students

To find out the vocabulary learning strategies that the second year students of King Mongkut's Institute of Technology Ladkrabang commonly use, the results were shown in Table II below:

TABLE II: MEAN $(\bar{x})$ AND STANDARD DEVIATION (SD) OF VOCABULARY LEARNING STRATEGIES $(N=365)$

\begin{tabular}{lcc|l}
\multicolumn{3}{c}{ LEARNING STRATEGIES $(N=365)$} & \\
\hline Vocabulary Learning Strategies & $\bar{x}$ & SD & Result \\
\hline Determination Strategies & & & \\
- Use an English-Thai dictionary & 2.86 & 1.007 & Usually used \\
- Look for any word parts that I & 1.68 & 1.009 & Seldom used \\
know & & & \\
Social Strategies & & & \\
- Ask my classmates for the meaning & 2.71 & 0.894 & Usually used \\
- Ask the teacher to check my & 1.49 & 1.025 & Seldom used \\
definition & & & \\
Memory Strategies & & & \\
- Remember the words in scales & 2.75 & 0.945 & Usually used \\
(always, often, sometimes, never). If & & & \\
it is used more, I spend more time to & & & \\
remember it. & & & \\
Write paragraphs using several new & 1.63 & 0.945 & Seldom used \\
words & & & \\
Cognitive Strategies & & & \\
- Keep a vocabulary notebook & 2.42 & 1.083 & Usually used \\
- Put English labels on physical & 1.31 & 1.091 & Seldom used \\
objects & & & \\
$\begin{array}{l}\text { Metacognitive Strategies } \\
\text { - Use English language media (song, } \\
\text { movies, the internet) }\end{array}$ & 2.51 & 1.008 & Usually used \\
- Skip or pass new words & 1.76 & 0.965 & Seldom used \\
\hline
\end{tabular}

Table II showed means and standard deviations of vocabulary learning strategies that the second year students of King Mongkut's Institute of Technology Ladkrabang used. The most used frequently strategies was determination, using an English-Thai dictionary ( $\bar{x}=2.86$ ). On the other hand, the less-used frequently strategies was cognitive strategies, putting English label on physical objects $(\bar{x}=1.31)$.

Fig. 1 below shows proportion of vocabulary learning strategies most-used by all learners. They were divided into 5 categories as follows: determination strategies $22 \%$, memory strategies $21 \%$, social strategies $20 \%$, cognitive strategies $18 \%$ and metacoginitive strategies $18 \%$ respectively.

\section{Overall Most-used vocabulary learning strategies}

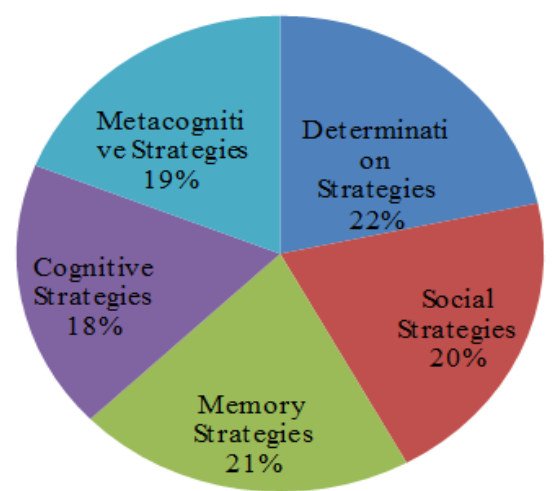

Fig. 1. Proportion of vocabulary learning strategies most-used by all learners.

\section{B. Most and Less Used Vocabulary Learning Strategies of Good and Weak Learners}

To discover most-used and less-used vocabulary learning strategies of good learners, the result was showed in Table III below: 
TABLE III: MEAN $(\bar{x})$ AND STANDARD DEVIATION OF GOOD LEARNERS' VOCABULARY LEARNING STRATEGIES $(N=60)$

\begin{tabular}{|c|c|c|c|}
\hline $\begin{array}{l}\text { Vocabulary Learning } \\
\text { Strategies }\end{array}$ & $\bar{x}$ & SD & Result \\
\hline \multicolumn{4}{|l|}{ Determination Strategies } \\
\hline $\begin{array}{l}\text { - Guess its meaning from } \\
\text { context }\end{array}$ & 3.32 & 0.833 & Usually used \\
\hline $\begin{array}{l}\text { - Look for any word parts that I } \\
\text { know }\end{array}$ & 2.08 & 1.139 & Seldom used \\
\hline \multicolumn{4}{|l|}{ Social Strategies } \\
\hline $\begin{array}{l}\text { - Study the word with my } \\
\text { classmates }\end{array}$ & 2.68 & 1.017 & Usually used \\
\hline $\begin{array}{l}\text { - Ask the teacher to check my } \\
\text { definition }\end{array}$ & 1.90 & 1.115 & Seldom used \\
\hline \multicolumn{4}{|l|}{ Memory Strategies } \\
\hline $\begin{array}{l}\text { - Remember the words in scales } \\
\text { (always, often, sometimes, } \\
\text { never). If it is used more, I spend } \\
\text { more time to remember it. }\end{array}$ & 2.88 & 1.327 & Usually used \\
\hline $\begin{array}{l}\text { - Draw a picture of the word to } \\
\text { help remember it }\end{array}$ & 1.97 & 1.327 & Seldom used \\
\hline \multicolumn{4}{|l|}{ Cognitive Strategies } \\
\hline $\begin{array}{l}\text {-Take notes or highlight new } \\
\text { words in class }\end{array}$ & 2.93 & 1.087 & Usually used \\
\hline $\begin{array}{l}\text { - Put English labels on physical } \\
\text { objects }\end{array}$ & 1.42 & 1.344 & Seldom used \\
\hline \multicolumn{4}{|l|}{ Metacognitive Strategies } \\
\hline $\begin{array}{l}\text { - Use English language media } \\
\text { (song, movies, the internet) }\end{array}$ & 2.93 & 1.039 & Usually used \\
\hline - Skip or pass new words & 1.82 & 1.142 & Seldom used \\
\hline
\end{tabular}

Table III showed means and standard deviations of vocabulary learning strategies. It shows that vocabulary learning strategies that good learners use most and less. The most used frequently strategies was determination, guessing its mean from context $(\bar{x}=3.32)$. The less used frequently strategies was cognitive strategies, putting English label on physical objects $(\bar{x}=1.31)$.

To discover most-and less-used vocabulary learning strategies of weak learners, the result was shown in Table IV below:

TABLE IV: MeAn $(\bar{x})$ AND STANDARD DEVIATION OF WEAK LEARNERS' VOCABULARY LEARNING STRATEGIES $(N=60)$

\begin{tabular}{|c|c|c|c|}
\hline Vocabulary Learning Strategies & $\bar{x}$ & SD & Result \\
\hline \multicolumn{4}{|l|}{ Determination Strategies } \\
\hline - Use an English-Thai dictio & 2.70 & 1.046 & Usually used \\
\hline - Look for any word parts that I know & 1.43 & 0.831 & Seldom used \\
\hline \multicolumn{4}{|l|}{ Social Strategies } \\
\hline - Ask my classmates for the meaning & 2.85 & 0.860 & Usually used \\
\hline $\begin{array}{l}\text { - Ask the teacher to check my } \\
\text { definition }\end{array}$ & 1.43 & 0.963 & Seldom used \\
\hline \multicolumn{4}{|l|}{ Memory Strategies } \\
\hline $\begin{array}{l}\text { - Remember the words in scales } \\
\text { (always, often, sometimes, never). If } \\
\text { it is used more, I spend more time to } \\
\text { remember it. }\end{array}$ & 2.73 & 0.936 & lly used \\
\hline $\begin{array}{l}\text { - Draw a picture of the word to help } \\
\text { remember it }\end{array}$ & 1.35 & 0.936 & Seldom used \\
\hline \multicolumn{4}{|l|}{ Cognitive Strategies } \\
\hline $\begin{array}{l}\text {-Take notes or highlight new words } \\
\text { in class }\end{array}$ & 2.43 & 1.031 & Usually used \\
\hline $\begin{array}{l}\text { - Put English labels on physical } \\
\text { objects }\end{array}$ & 1.32 & 0.911 & Seldom used \\
\hline \multicolumn{4}{|l|}{ Metacognitive Strategies } \\
\hline $\begin{array}{l}\text { - Use English language media (song, } \\
\text { movies, the internet) }\end{array}$ & 2.32 & 1.033 & Usually used \\
\hline - Study new words many times & 1.68 & 0.854 & Seldom used \\
\hline
\end{tabular}

Table IV showed means and standard deviations of vocabulary learning strategies that weak learners use most and less. The most used frequently strategies was social, asking my classmates for the meaning $(\bar{x}=2.85)$. The less used frequently strategies was cognitive strategies, putting English label on physical objects $(\bar{x}=1.32)$.

The following Fig. 2 shows comparison of vocabulary learning strategies most-used by good and weak learners. It was found that good learners used more frequently strategies than weak learners, except social strategies.

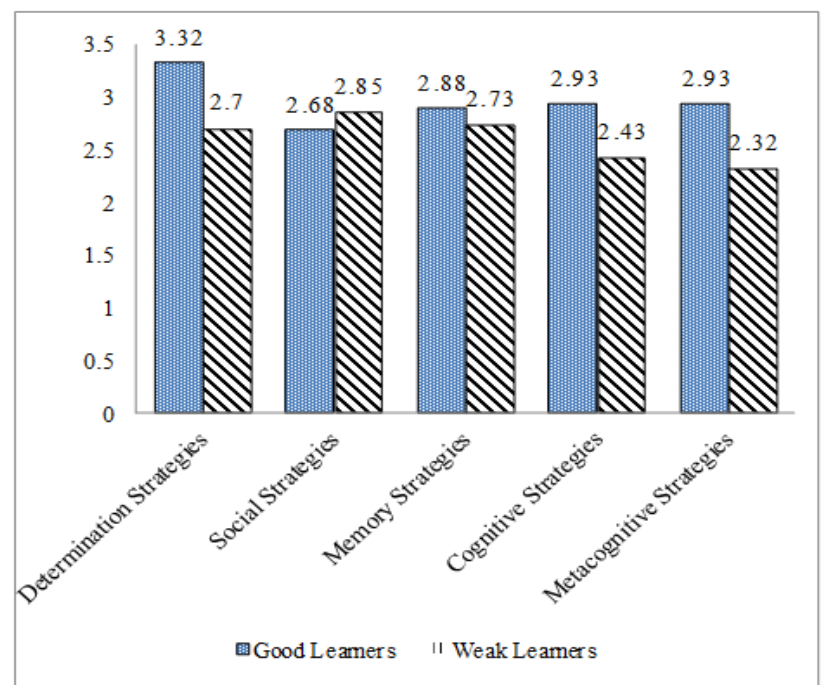

Fig. 2. Comparison most-used of vocabulary learning strategies by good and weak learners.

TABLE V: TEN MOST USED OF VOCABULARY LEARNING STRATEGIES USING BY GOOD AND WEAK LEARNERS

\begin{tabular}{|c|c|c|c|c|}
\hline No. & Good Learners & $\bar{x}$ & Weak Learners & $\bar{x}$ \\
\hline 1 & $\begin{array}{l}\text { Guess its meaning } \\
\text { from context }\end{array}$ & 3.32 & $\begin{array}{l}\text { Ask my classmates for } \\
\text { the meaning }\end{array}$ & 2.85 \\
\hline 2 & $\begin{array}{l}\text { Use a English-Thai } \\
\text { dictionary }\end{array}$ & 3.1 & $\begin{array}{l}\text { Remember the words } \\
\text { in scales (always, } \\
\text { often, sometimes, } \\
\text { never). If it is used } \\
\text { more, I spend more } \\
\text { time to remember it. }\end{array}$ & 2.73 \\
\hline 3 & $\begin{array}{l}\text { Take notes or } \\
\text { highlight new words in } \\
\text { class }\end{array}$ & 2.93 & $\begin{array}{l}\text { Use a English-Thai } \\
\text { dictionary }\end{array}$ & 2.7 \\
\hline 4 & $\begin{array}{l}\text { Use English language } \\
\text { media (song, movies, } \\
\text { the internet) }\end{array}$ & 2.93 & $\begin{array}{l}\text { Guess its meaning } \\
\text { from context }\end{array}$ & 2.6 \\
\hline 5 & $\begin{array}{l}\text { Pay attention to } \\
\text { English words when } \\
\text { someone is speaking } \\
\text { English }\end{array}$ & 2.92 & $\begin{array}{l}\text { Use new words in } \\
\text { sentences. }\end{array}$ & 2.53 \\
\hline 6 & $\begin{array}{l}\text { Remember the words } \\
\text { in scales (always, } \\
\text { often, sometimes, } \\
\text { never). If it is used } \\
\text { more, I spend more } \\
\text { time to remember it. }\end{array}$ & 2.88 & $\begin{array}{l}\text { Take notes or } \\
\text { highlight new words } \\
\text { in class }\end{array}$ & 2.43 \\
\hline 7 & $\begin{array}{l}\text { Connect the word to } \\
\text { other with similar or } \\
\text { opposite meaning }\end{array}$ & 2.73 & $\begin{array}{l}\text { Use English language } \\
\text { media (song, movies, } \\
\text { the internet) }\end{array}$ & 2.32 \\
\hline 8 & $\begin{array}{l}\text { Use any pictures or } \\
\text { gestures to help me } \\
\text { guess the meaning }\end{array}$ & 2.72 & $\begin{array}{l}\text { Keep a vocabulary } \\
\text { notebook }\end{array}$ & 2.28 \\
\hline 9 & $\begin{array}{l}\text { Connect the word to a } \\
\text { personal experience }\end{array}$ & 2.72 & $\begin{array}{l}\text { Pay attention to } \\
\text { English words when } \\
\text { someone is speaking } \\
\text { English }\end{array}$ & 2.27 \\
\hline 10 & $\begin{array}{l}\text { Use new words in } \\
\text { sentences. }\end{array}$ & 2.68 & $\begin{array}{l}\text { Connect the word to } \\
\text { other with similar or } \\
\text { opposite meaning }\end{array}$ & 2.23 \\
\hline
\end{tabular}


Table V shows ten most used of vocabulary learning strategies using by good and weak learners. The most used strategy used by good learners was guessing its meaning from context. The most used strategy used by weak learners was asking my classmates for the meaning.

\section{Comparison of Significant Differences of Vocabulary Learning Strategies Use between the Good and Weak Learners}

To compare the vocabulary learning strategies that were used by good and weak learners, the result was showed in Table VI below:

TABLE VI: MEAN $(\bar{x})$ AND INDEPENDENT SAMPLE T-TEST OF VOCABULARY LEARNING STRATEGIES USING $(N=120)$

\begin{tabular}{llll}
\multicolumn{3}{c}{ VOCABULARY LEARNING STRATEGIES USING $(N=120)$} \\
\hline $\begin{array}{l}\text { Vocabulary } \\
\text { Learning } \\
\text { Strategies }\end{array}$ & $\begin{array}{l}\bar{x} \\
\text { Good } \\
\text { Learners }\end{array}$ & $\begin{array}{l}\bar{x} \\
\text { Weak } \\
\text { Learners }\end{array}$ & $\begin{array}{c}\text { Sig.(2tailed) } \\
\text { *Significant }\end{array}$ \\
\hline $\begin{array}{l}\text { Determination } \\
\text { Strategies }\end{array}$ & 2.670 & 2.061 & $0.005^{*}$ \\
$\begin{array}{l}\text { Social Strategies } \\
\text { Memory }\end{array}$ & 2.372 & 2.042 & $0.029^{*}$ \\
Strategies & 2.342 & 1.848 & $0.000^{*}$ \\
$\begin{array}{l}\text { Cognitive } \\
\text { Strategies }\end{array}$ & 2.220 & 1.872 & 0.257 \\
$\begin{array}{l}\text { Metacognitive } \\
\text { Strategies }\end{array}$ & 2.414 & 2.000 & 0.085 \\
Significance at level $\leq 0.05$ & & \\
\hline
\end{tabular}

From Table VI, the finding indicated that there was a contrast of the strategies usage between good and weak learners, which demonstrated that good learners used strategies more frequently than weak learners. There was significant difference between good and weak learners in determination $\left(0.005^{*}\right)$, social $\left(0.029^{*}\right)$, and memory $\left(0.000^{*}\right)$ strategies. No significant difference was identified between the other two strategies, cognitive (0.257) and metacognitive (0.085) strategies.

Fig. 3 below shows that good learners all used learning strategies more frequently than weak learners i.e. determination, social, memory, cognitive and metacognitive.

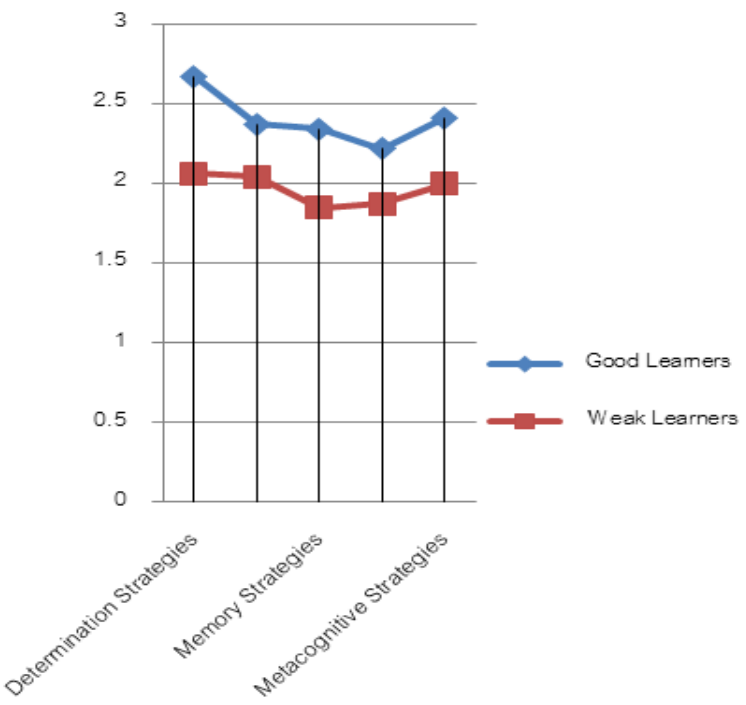

Fig. 3. Overall vocabulary learning strategies using between good and weak learners.

\section{CONCLUSION AND DISCUSSION}

In conclusion, it was found that the research subjects used the vocabulary learning strategies in all five categories at a moderate level. The most frequently used strategies by all subjects belonged to determination strategies, while the cognitive strategies were used the lowest level by all subjects. The finding about the most frequently strategies used by good learners were similar to overall. On the other hand, the social strategy was frequently used by weak learners. In terms of the significant differences between good and weak learners, it was revealed that the good learners used vocabulary learning strategies more often than weak learners at $0.00^{*}$ level.

In this research, this finding was consistent with the previous studies in terms of the strategies used in English vocabulary learning by university students. Therefore, this study confirmed earlier reported findings that good language learners are heavily dependent on bilingual dictionaries for their English vocabulary learning. We can see that the most popular strategies used by the students were similar to [2], [14], [15]. The results showed that the bilingual English-Thai dictionary was the most-used strategy for students at the university level. It confirmed that using bilingual dictionary is important to language learning. It helps students to discover new word's meaning. The research invites follow-up research on the relationship between dictionary reference skills and comprehension, and whether frequent and careful consultation of a bilingual dictionary does indeed lead to a better command of English. More research is needed that the dictionary has a role to play in the vocabulary acquisition and development of students' vocabulary.

\section{ACKNOWLEDGMENT}

I would like to take this opportunity to acknowledge my advisor, Assoc. Prof. Dr. Jirapa Vitayapirak for her continual support, uplifting encouragement, and valuable advice.

\section{REFERENCES}

[1] M. J. McCarthy, Vocabulary, Oxford: Oxford University Press, 1990.

[2] N. Schmitt and M. MaCarthy, Vocabulary: Description, Acquisition and Pedagogy, Cambridge: Cambridge University Press, 1997.

[3] V. F. Allen, Techniques in Teaching Vocabulary, New York: Oxford University Press, 1983.

[4] T. Hedge, Teaching and Learning in the Language Classroom, Oxford: Oxford University Press, 2000.

[5] H. Jackson and E. Z. Amvela, Words, Meaning and Vocabulary: An Introduction to Modern English Lexicology, London: Cassell, 2000.

[6] A. Maley, "Series editors' preface," in Vocabulary, J. Morgan and M. Rinvolucri, Eds. Oxford: Oxford University Press, 1986.

[7] P. Meara, "Vocabulary acquisition: A neglected aspect of language learning," Language Teaching and Linguistics Abstracts, vol. 13, pp. 221-246, 1980.

[8] C. B. Zimmerman, "Do reading and interactive vocabulary instruction make difference? An empirical study," TESOL Quarterly, vol. 32, pp. 121-140, 1997.

[9] M. Williams and R. L. Burden, Psychology for Language Teacher: Social Constructivist Approach, Cambridge: Cambridge University Press, 1997.

[10] E. Tarone, Strategies in Interlanguage Communication, London: Longman, 1983.

[11] J. Rubin and A. Wenden, Learners Strategies in Language Learning, New Jersey: Prentice-Hall International, 1987.

[12] J. M. O'Malley and A. U. Chamot, Learning Strategies in Second Language Acquisition, New York: Cambridge University Press, 1990.

[13] R. Oxford, Language Learning Strategies: What Every Teacher Should Know, New York: Newbury House Publisher, 1990. 
[14] P. Mingsakoon, "A comparative study of vocabulary learning strategies between mattayom suka six students in science and arts programs at Hunkapittayakom school, Chainat province/ Pajonsak Mingsakoon,” Bangkok: Mahidol University, 2003.

[15] N. Mongkol, "A study of vocabulary learning strategies of the first and second year students from English department at Phetchaburi Rajabhat University,” Bangkok: Kasetsart University, 2008.

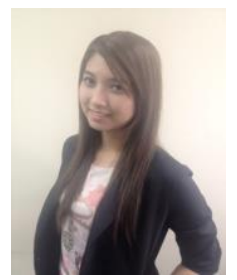

Khanadee Rojananak was born on 13 July, 1983 in Bangkok, Thailand. In 2004, she graduated from Ramkhamhaeng University, Bangkok, Thailand. She received her bachelor degree of arts (English). At present, she is the secretary of the director of General Education Office at Dusit Thani College, Bangkok Thailand. Her research interests is vocabulary learning.

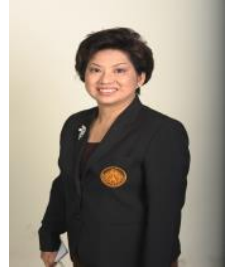

Jirapa Vitayapirak works at the Department of Applied Arts (English), Faculty of Industrial Education, King Mongkut's Institute of Technology Ladkrabang, Thailand. In 1986, she got her M.A. degree in applied linguistics, from King Mongkut's University of Technology Thonburi, Thailand and then she received her Ph.D. degree in linguistics, form Macquarie University, Australia in 2001. In 1996 she was the associate dean for Academic Affairs, Faculty of Industrial Education, King Mongkut's Institute of Technology Ladkrabang. Her research interests are corpus lexicography, ESP, ELT and terminology. In 2008 to 2009 she was the president of the Asian Association for Lexicography (ASIALEX). 